\title{
THE IMPACT OF GENDER ON FOOD WASTE AT THE CONSUMER LEVEL
}

\author{
Ramona Cantaragiu* \\ The Bucharest University of Economic Studies, Bucharest, Romania \\ E-mail: ramona_cantaragiu@yahoo.com
}

(Received: July 2019; Accepted: September 2019; Published: November 2019)

\begin{abstract}
Food waste is one of the main contributors to economic disparities, social inequalities and environmental pollution. Numerous studies have sought to understand the drivers of food waste at various stages in the food supply chain, including the consumption stage. Based on a quantitative analysis of 252 Romanian consumers, the present study shows that gender is an important factor that affects the individuals' attitudes and behaviours in regard to food and a potential factor that could affect the amount of food wasted. The study found that attitudes towards food waste evolve as individuals age, and that, at each stage, women tend to be more concerned about the negative impact of food waste on social equity or the family budget than men. In addition, women were found to display behaviours in regard to food acquisition and preparation that can result in higher food waste in a larger degree than men, even though the study found no differences in the actual amount of food wasted by the two genders. The results of the study are important because they show the need to adapt the public awareness campaigns on food waste on the particularities of each gender across several age groups.
\end{abstract}

Keywords: food waste, food attitudes, consumer behaviour, gender.

JEL Codes: M10, M31.

\section{Introduction}

Food waste is nowadays a major concern for both developed and underdeveloped countries because it leads to market inefficiencies, social inequality and environmental pollution, which, overall, threaten the sustainability of life on the planet. According to the most recent statistics published by the Food and

\footnotetext{
${ }^{*}$ Corresponding author: Ramona Cantaragiu.E-mail: ramona_cantaragiu@yahoo.com
} 
Cantaragiu, R., (2019)

The impact of gender on food waste at the consumer level

Agriculture Organization of the United Nations (FAO, 2019), approximately one third of the food produced at a global level (i.e., 1.3 billion tons) is wasted every year and individuals in developed countries waste as much food (222 mil tons) as the entire food production in sub-Saharan Africa (203 mil tons). However, the causes of food waste differ in each country depending on the level of economic development: in underdeveloped countries almost $40 \%$ of the food waste is a result of inadequate processing and storage of raw materials (i.e., at the production stage), whereas in developed countries more than $40 \%$ of the food waste is a result of market inefficiencies (i.e., at the retail and consumption stages) (FAO, 2019). Food waste is defined differently by researchers and organizations, but for the purposes of the current paper, it will be defined as "any food, and edible parts of food, removed from the food supply chain to be recovered or disposed (including composted, crops ploughed in/not harvested, anaerobic digestion, bio-energy production, co-generation, incineration, disposal to sewer, landfill or discarded at sea)" (Fusions, 2016).

Numerous international and national organizations have sought to find effective waste to combat food waste by instituting public policies, investing in public awareness campaigns and fostering social entrepreneurial initiatives that help both consumers and producers reduce the amount of food that is disposed of in landfills. The main targets of most of public awareness campaigns have been individual consumers, because they represent the link in the food chain that generates the most food waste, at least in developed countries. However, these campaigns have had varying levels of effectiveness and this signals the need to understand how each individual consumer understand and contributes to food waste.

The present study is focused on the exploration of the impact of gender on food waste at the consumer level, a socio-demographic factor whose influence on food waste is highly debated in the scientific literature. The first section provides an overview of previous studies on the topic and establishes the need for further research, while the second section presents the research methodology that forms the basis of the current study. The results are presented in the third section and are followed by a series of discussions and suggestions for future studies.

\section{Literature review}

In general, there is no general agreement among researchers regarding the impact of gender on the behaviours and attitudes that lead to food waste. According to some studies, women are less likely to waste food products in comparison to men (Barr, 2007; Secondi, Principato, Laureti, 2015; Visschers et al., 2016). However, other studies have provided contradictory findings either regarding the behaviour of single women, who are said to produce more food waste in comparison to single men or couples (Silvennoinen et al., 2014; Koivupuro et al., 2012), or the

42 sciendo Studia Universitatis "Vasile Goldis" Arad. Economics Series Vol 29 Issue 4/2019 ISSN: 1584-2339; (online) ISSN: 2285 - 3065

Web: publicatii.uvvg.ro/index.php/studiaeconomia. Pages $41-57$ 
Cantaragiu, R., (2019)

The impact of gender on food waste at the consumer level

behaviour of young females, who are said to produce the same amount of food waste as young males (Principato, Secondi, Pratesi, 2015). This signals the fact that it is very likely that the behaviour of women changes once they grow older and begin forming couples, when their responsibilities in the household change.

When it comes to attitudes towards food acquisition, preparation, consumption and disposal, gender appears to be a significant factor, mainly due to the gender segregation of household responsibilities. In most households where individuals of both genders reside, women are usually the ones responsible for grocery shopping (McCarthy \& Liu, 2017) and for preparing the meals for the entire household (Koivupuro et al., 2012). Studies have found that women are more likely to purchase local food and organic food products because they show a higher tendency towards being concerned with the nutritional and sustainability aspects related to food (Cholette et al., 2013). This can have a positive impact on the amount of food wasted by women because previous studies have shown that the individuals who buy local produce waste less vegetables and fruits (Setti et al., 2016) or less food products overall (Jorissen, Priefer \& Brautigam, 2015). However, Koivupuro et al. (2012) and Katajuuri et al. (2014) found that in the households where women or both men and women are responsible for grocery shopping more food waste is generated than in the households where men attend to food purchasing responsibilities.

In addition, women are also usually responsible for cooking and feeding their families. Studies have shown that women tend to often express feelings of guilt when they waste food because they take this as a sign that they are not properly managing the household and that they are failing to provide sustenance to their family members (Lyndhurst, 2007). Similar findings were provided by Qi and Roe's (2016) study which reported that women are more likely to feel guilty when having to throw away food items. In addition, even though women who are also mothers are usually willing to put the preferences of the other household members above their own in what regards food, i.e., a behaviour that Cappellini and Parsons (2012) term as sacrifice, studies have consistently shown that when women adopt the role of the "good provider" (Graham-Rowe, Jessop \& Sparks, 2014) or of the "good mother" (Porpino, 2016), more food is wasted in the household because the women's preferences for thrift and recycling of food leftovers are sacrificed in favour of the preferences of the other family members, especially children. In fact, studies have consistently shown that households where children are present waste more food than households without children (Secondi et al., 2015).

Finally, there are several contradictory findings regarding the impact of gender on food recycling attitudes and behaviours. For example, Lee and Paik (2011) found that gender has no impact on food separation behaviour or recycling behaviour, while Graham-Rowe, Jessop and Sparks (2015) found that women are more likely 
Cantaragiu, R., (2019)

The impact of gender on food waste at the consumer level

to express interest in reducing the amount of fruits and vegetables wasted by their households. In addition, Porpino (2016) found that gender affects the perception of situational factors in the household, which, in turn, affects the behaviour related to waste separation in the household.

An analysis of the previous studies on the matter of the impact of gender on the amount of food wasted in households reveals that, in the case of women, there are several factors, which affect their decisions in regard to food acquisition, preparation and disposal. On the one hand, women seem more attuned to the fact that food waste creates negative consequences for the environment and for society as a whole, and, as a result, are more willing to introduce changes in their behaviour in order to reduce food waste. On the other hand, women are usually the ones responsible for providing sustenance to their families, which impedes their ability to reduce food waste as they have to take into account the preferences of the other household members which, especially in the case of children, might not be influenced by the awareness that certain acquisition and consumption patterns (e.g., buying more food than they can consume before it expires or choosing to eat outside when there is cooked food at home) lead to food waste.

\section{Research Methodology}

The main purpose of the research is to investigate the impact of gender on individual's behaviour and attitudes related to food consumption and food waste. The analysis is based on 33 items related to the aforementioned topic, which were included in a multiple topic survey conducted between December 2018 - January 2019 among Romanian participants from urban areas. The total sample included 252 participants, out of which $52.4 \%$ were female participants and $47.6 \%$ were male participants. Based on the fact that previous studies have signalled the importance of age when it comes to the behaviour and attitudes of both males and females in relation to food consumption and food waste, the following research questions were formulated:

RQ1: What is the impact of gender on food waste attitudes and behaviours across different age groups?

RQ2: What is the impact of gender of the amount of food wasted across different age groups?

Data was analysed using independent t-tests and cross-tabs in IBM SPSS v.13. The 33 items related to food waste were scored on a Likert scale from 1 (completely disagree) to 7 (completely agree). The items are presented in Table 1. 
Cantaragiu, R., (2019)

The impact of gender on food waste at the consumer level

\section{Table 1 Items related to food waste}

\begin{tabular}{|c|c|}
\hline I1 & I plan my food shopping trips ahead and I make a list to know what to buy. \\
\hline $\mathbf{I 2}$ & I tend to buy food items that are not on the shopping list. \\
\hline $\mathbf{I 3}$ & I have a fixed schedule for going food shopping (e.g., once a week). \\
\hline I4 & $\begin{array}{l}\text { I buy food products even though they have visual defects as long as they are } \\
\text { edible. }\end{array}$ \\
\hline $\mathbf{I 5}$ & I tend to buy food products with longer expiration dates. \\
\hline I6 & In general, I do not buy food items for a particular recipe. \\
\hline I7 & Food packaging contains too much food for my needs. \\
\hline I8 & I tend to buy more food than I need to make provisions for unexpected events. \\
\hline I9 & When I am hungry, I tend to buy more food. \\
\hline $\mathbf{I 1 0}$ & For holidays and special occasions, I tend to buy more food than necessary. \\
\hline I11 & I think that an abundant food offering is a sign of social status. \\
\hline I12 & I spend a lot of time shopping for food. \\
\hline I13 & I like to buy new food items to try them out. \\
\hline I14 & $\begin{array}{l}\text { I check the expiration date of food items and consume those that are about to } \\
\text { expire. }\end{array}$ \\
\hline I15 & I consume food items after the expiration date if they look good. \\
\hline I16 & I freeze food items to preserve them for longer periods of time. \\
\hline I17 & I store food items in proper conditions in order to prolong their life. \\
\hline I18 & I tend to cook more food than is consumed in the household. \\
\hline I19 & I have the ability to use the food items at my disposal to improvise a recipe. \\
\hline $\mathbf{I 2 0}$ & I cook and eat at home every day. \\
\hline $\mathbf{I 2 1}$ & I reuse the food items left from the previous day. \\
\hline $\mathbf{I 2 2}$ & I prefer to eat out even though there is cooked food in the fridge. \\
\hline $\mathbf{I 2 3}$ & I reuse the food items to feed the animals in the household. \\
\hline $\mathbf{I 2 4}$ & I recycle leftovers to make compost. \\
\hline $\mathbf{I 2 5}$ & I throw away food even if it is edible, if I know that I am not going to eat it. \\
\hline $\mathbf{I 2 6}$ & I tend to keep food until it is not edible anymore in the hope that I will eat it. \\
\hline $\mathbf{I 2 7}$ & I throw away food at the first signs of alteration. \\
\hline $\mathbf{I 2 8}$ & I donate the food that I cannot eat to poor families. \\
\hline I29 & I think I throw away more food than the rest of people. \\
\hline I30 & I feel guilty whenever I want to throw away food. \\
\hline I31 & Every time I throw away food, I think about the money spent. \\
\hline I32 & $\begin{array}{l}\text { Every time I throw away food, I think about poor children who do not have } \\
\text { enough to eat. }\end{array}$ \\
\hline I33 & iated a higher amount of food wasted with a food crisis. \\
\hline
\end{tabular}

Source: Author's own research design

Besides these 33 items, the questionnaire also included a question referring to the amount of food wasted by the participants which was a multiple-choice question with the following responses: a) under 10\%; b) between $10 \%$ and $30 \%$; c) between 
Cantaragiu, R., (2019)

The impact of gender on food waste at the consumer level

$30 \%$ and $50 \%$; d) above 50\%. The age of the participants was measured using a multiple-choice question with the following responses: a) under 20; b) between 20 and 30; c) between 30 and 40; d) between 40 and 50; e) between 50 and 60; over 60.

\section{Empirical results}

In order to answer the first research question, we performed a series of independent t-tests for the significance of the means for the 33 items included in the questionnaire obtained from the responses of male and female participants across five major age groups: under 20 years old, between 20 and 30 years old, between 30 and 40 years old, between 40 and 50 years old, between 50 and 60 years old and over 60 years old. The results of the statistical tests for the age groups below 40 are displayed in Figure 1 and in Tables 4 and 5 in the Annex section.

I check the expiration date of food items and consume those that are about to expire.

- Males under 20 - mean 5.429

- Females under 20 - mean 3.200

I tend to cook more food than is consumed in the household.

- Males between 20 and 30 - mean 3.683

-Females between 20 and 30 - mean 4.458

Figure 1 The impact of gender on food waste for age groups below 40 Note: Only mean differences significant under $\mathrm{p}<0.05$ shown.

Source: Authors' research results.

As can be seen from Table 4 and Figure 1, for the under 20 years old, the sole statistically significant difference in means between the answers reported by male and female participants was registered for the item "I check the expiration date of food products and I consume those products which are about to expire". Females reported an average of 3.200, while males reported an average of $5.429(\mathrm{p}<0.05)$ which means that male participants are most likely to adapt their consumption patterns in such a way as to avoid throwing away food that was not consumed before its expiration date.

In addition, for the age category between 20 and 30 years old, the results in Table 4 , show that there was a statistically significant difference in the means of the answers of male and female participants recorded for the item "I tend to cook more food than the amount consumed". Females reported an average level of agreement with the item of 4.458 , while males reported an average of only $3.683(\mathrm{p}<0.05)$. 
Cantaragiu, R., (2019)

The impact of gender on food waste at the consumer level

This signals that male participants from this age category are more likely than their female counterparts to adapt their food preparation activities to the actual amount of food consumed, which can result in less food waste.

According to the results shown in Figure 2 and Table 5 from the Annex section, the female participants from this age category are also more likely to feel bad when being forced to throw away food (average response of 5.407 in comparison to 4.195 for males, $\mathrm{p}<0.05$ ) and to think about the children who do not have enough to eat when throwing food items (average response of 4.780 in comparison to 3.439 for males, $\mathrm{p}<0.05$ ). Thus, we can conclude that females with ages between 20 and 30 years have a higher tendency both to cook more food than their household can consume and to feel more guilty after throwing food away in comparison to their male counterparts.

\section{I feel guilty whenever I want to throw away food.}

- Males between 20 and 30 - mean 4.195

- Females between 20 and 30 - mean 5.407

Every time I throw away food, I think about poor children who do not have enough to eat.

- Males between 20 and 30 - mean 3.439

-Females between 20 and 30 - mean 4.780

I cook and eat at home every day.

- Males between 30 and 40 - mean 2.800

-Females between 30 and 40 - mean 3.958

I have the ability to use the food items at my disposal to improvise a recipe.

- Males between 30 and 40 - mean 3.720

-Females between 30 and 40 - mean 5.583

Every time I throw away food, I think about the money spent.

- Males between 30 and 40 - mean 3.720

- Females between 30 and 40 - mean 4.875

Figure 2 The impact of gender on food waste for age groups below 40 (cont.) Note: Only mean differences significant under $\mathrm{p}<0.05$ shown.

Source: Authors' research results. 
Cantaragiu, R., (2019)

The impact of gender on food waste at the consumer level

For the age category between 30 and 40 years old, the significant differences regard cooking habits and pragmatic reasons that reduce food waste. First, for the item "I have the ability to use the food items at my disposal in order to improvise a recipe", the female participants in this age category expressed an average level of agreement of 5.583, while their male counterparts expressed an average level of agreement of only $3.720(\mathrm{p}<0.05)$. Second, for the item "I cook and eat at home every day", the female participants in this age category expressed an average level of agreement of 3.958, while their male counterparts expressed an average level of agreement of only $2.800(\mathrm{p}<0.05)$. This signals the fact that the female participants from this age category have better cooking skills and tend to cook and eat at home more than their male counterparts. Third, for the item "Whenever I throw away food, I think about the money I have spent", the female participants in this age category expressed an average level of agreement of 4.875 , while the male participants expressed a lower level of agreement $(3.720, \mathrm{p}<0.05)$. This signals that the women in this age category are more concerned about the financial impact of food waste than their male counterparts.

As can be seen in Figures 3 and 4 and in Tables 6 and 7 from the Annex section, the impact of gender on food attitudes and behaviours for the age groups over 40 years old is not as high as for the previous age groups. For the age group between 40 and 50 years old, the female participants reported a level of agreement with the item "I tend to buy food items that are not on the shopping list" of 5.273, while their male counterparts reported an average level of agreement of $4.000(\mathrm{p}<0.05)$. In addition, the female participants from this age category expressed a level of agreement with the item "Whenever I throw away food, I think about the children who do not have enough to eat" of 4.864, while their male counterparts reported a level of agreement of only 3.059 ( $p<0.05$ ). This shows that the women in this age category are more likely to waste food as a result of over-shopping and also to consider the negative consequences that food waste has on social inequality in comparison to their male counterparts.

48 S sciendo Studia Universitatis "Vasile Goldis" Arad. Economics Series Vol 29 Issue 4/2019 ISSN: 1584-2339; (online) ISSN: $2285-3065$

Web: publicatii.uvvg.ro/index.php/studiaeconomia. Pages $41-57$ 
Cantaragiu, R., (2019)

The impact of gender on food waste at the consumer level

I tend to buy food items that are not on the shopping list.

- Males between 40 and 50 - mean 4.000

-Females between 40 and 50 - mean 5.273

I spend a lot of time shopping for food.

-Males between 50 and 60 - mean 2.950

-Females between 50 and 60 - mean 4.222

Every time I throw away food, I think about poor children who do not have enough to eat.

-Males between 40 and 50 - mean 3.059

-Females between 40 and 50 - mean 4.864

Figure 3 The impact of gender on food waste for age groups over 40

Note: Only mean differences significant under $\mathrm{p}<0.05$ shown.

Source: Authors' research results.

In what regards the age category between 50 and 60 years old, the only significant difference in means was registered for the item "I spend a lot of time when I go shopping", where the female participants expressed an average level of agreement of 4.222, while their male counterparts reported an average level of agreement of only $2.950(p<0.05)$. This can result in higher amounts of food waste, but there were not significant differences in regard to the response for the item concerning the acquisition of food items from the shopping lis, which means that this type of behaviour does not necessarily imply that women buy more food items than planned. For the final age category, over 60 years old, there were no significant differences registered between the male's and female's participants behaviours and attitudes about food.

In order to answer the second research question, we performed a cross tabulation between gender and amount of food wasted for each age category and calculated the Phi value. The results are displayed in Table 2. Based on the results, it can be concluded that the majority of the participants wasted less than $30 \%$ of the food and that there were no significant gender differences across the age categories under analysis. Thus, even though there are certain significant differences in the attitudes towards food and the practices related to food acquisition, preparation and consumption between the female and male participants in the study, these differences do not amount to significant differences in the actual percentage of the food that is wasted. 
Cantaragiu, R., (2019)

The impact of gender on food waste at the consumer level

Table 2 The impact of gender on the amount of food wasted across all age categories

\begin{tabular}{|c|c|c|c|c|c|c|c|}
\hline \multirow{2}{*}{$\begin{array}{c}\text { Age } \\
\text { category }\end{array}$} & \multirow{2}{*}{ Gender } & \multicolumn{4}{|c|}{ Amount of food wasted (count) } & \multicolumn{2}{|c|}{$\begin{array}{c}\text { Symmetric } \\
\text { measures }\end{array}$} \\
\hline & & $\begin{array}{c}\text { Below } \\
10 \%\end{array}$ & $\begin{array}{l}\text { Between } \\
10-30 \%\end{array}$ & $\begin{array}{l}\text { Between } \\
\text { 30-50\% }\end{array}$ & $\begin{array}{l}\text { Over } \\
\mathbf{5 0 \%}\end{array}$ & $\begin{array}{c}\text { Phi } \\
\text { value }\end{array}$ & $\begin{array}{l}\text { Approx. } \\
\text { sig. }\end{array}$ \\
\hline \multirow{2}{*}{ Under 20} & $\mathrm{~F}$ & 1 & 4 & 0 & 0 & \multirow{2}{*}{-0.076} & \multirow{2}{*}{0.793} \\
\hline & $\mathrm{M}$ & 1 & 6 & 0 & 0 & & \\
\hline \multirow{2}{*}{$\begin{array}{l}\text { Between } \\
20 \text { and } 30\end{array}$} & $\mathrm{~F}$ & 28 & 22 & 6 & 3 & \multirow{2}{*}{0.161} & \multirow{2}{*}{0.462} \\
\hline & $\mathrm{M}$ & 20 & 18 & 3 & 0 & & \\
\hline \multirow{2}{*}{$\begin{array}{l}\text { Between } \\
30 \text { and } 40\end{array}$} & $\mathrm{~F}$ & 10 & 8 & 5 & 1 & \multirow{2}{*}{0.284} & \multirow{2}{*}{0.266} \\
\hline & $\mathrm{M}$ & 9 & 14 & 2 & 0 & & \\
\hline \multirow{2}{*}{$\begin{array}{l}\text { Between } \\
40 \text { and } 50\end{array}$} & $\mathrm{~F}$ & 10 & 7 & 5 & 0 & \multirow{2}{*}{0.270} & \multirow{2}{*}{0.240} \\
\hline & $\mathrm{M}$ & 7 & 9 & 1 & 0 & & \\
\hline \multirow{2}{*}{$\begin{array}{l}\text { Between } \\
50 \text { and } 60\end{array}$} & $\mathrm{~F}$ & 13 & 5 & 0 & 0 & \multirow{2}{*}{0.224} & \multirow{2}{*}{0.387} \\
\hline & $\mathrm{M}$ & 13 & 5 & 2 & 0 & & \\
\hline \multirow{2}{*}{ Over 60} & $\mathrm{~F}$ & 2 & 2 & 0 & 0 & \multirow{2}{*}{0.091} & \multirow{2}{*}{0.733} \\
\hline & $\mathrm{M}$ & 6 & 4 & 0 & 0 & & \\
\hline
\end{tabular}

Source: Author's research results.

A summary of the main findings is presented in Table 3 below.

Table 3 Gender differences in regard to food attitudes and behaviours

\begin{tabular}{|c|c|c|c|}
\hline $\begin{array}{c}\text { Age } \\
\text { category }\end{array}$ & $\begin{array}{c}\text { Differences in food } \\
\text { behaviours }\end{array}$ & $\begin{array}{c}\text { Differences in attitudes } \\
\text { towards food waste }\end{array}$ & $\begin{array}{c}\text { Differences in } \\
\text { amount of food } \\
\text { wasted }\end{array}$ \\
\hline Under 20 & $\begin{array}{c}\text { Males tend to give priority to } \\
\text { food about to expire }\end{array}$ & $\begin{array}{c}\text { No differences between } \\
\text { genders }\end{array}$ & $\begin{array}{c}\text { No differences } \\
\text { between genders }\end{array}$ \\
\hline $\begin{array}{c}\text { Between } \\
\text { and 30 }\end{array}$ & $\begin{array}{c}\text { Females tend to cook more } \\
\text { than is consumed }\end{array}$ & $\begin{array}{c}\text { Females tend to feel guilty } \\
\text { about food waste } \\
\text { Females tend to associate } \\
\text { food waste with social } \\
\text { inequality }\end{array}$ & $\begin{array}{c}\text { No differences } \\
\text { between genders }\end{array}$ \\
\hline $\begin{array}{c}\text { Between } \\
\text { and 40 }\end{array}$ & $\begin{array}{c}\text { Females have better cooking } \\
\text { skills }\end{array}$ & $\begin{array}{c}\text { Females tend to associate } \\
\text { food waste with financial } \\
\text { irresponsibility }\end{array}$ & $\begin{array}{c}\text { No differences } \\
\text { between genders }\end{array}$ \\
\hline $\begin{array}{c}\text { Between } \\
\mathbf{4 0} \text { and 50 }\end{array}$ & $\begin{array}{c}\text { Females tend to buy food } \\
\text { items that are not on the } \\
\text { shopping list }\end{array}$ & $\begin{array}{c}\text { Females tend to associate } \\
\text { food waste with social } \\
\text { inequality }\end{array}$ & $\begin{array}{c}\text { No differences } \\
\text { between genders }\end{array}$ \\
\hline $\begin{array}{c}\text { Between } \\
\mathbf{5 0} \text { and 60 }\end{array}$ & $\begin{array}{c}\text { Females spend more time } \\
\text { shopping for food }\end{array}$ & $\begin{array}{c}\text { No differences between } \\
\text { genders }\end{array}$ & $\begin{array}{c}\text { No differences } \\
\text { between genders }\end{array}$ \\
\hline Over 60 & $\begin{array}{c}\text { No differences between } \\
\text { genders }\end{array}$ & $\begin{array}{c}\text { No differences between } \\
\text { genders }\end{array}$ & $\begin{array}{c}\text { No differences } \\
\text { between genders }\end{array}$ \\
\hline
\end{tabular}

Source: Author's research results. 
Cantaragiu, R., (2019)

The impact of gender on food waste at the consumer level

\section{Conclusions}

The main findings show that there is a difference between the behaviour in regard to food of male and female consumers across age categories. For the participants below 30 years old, the study has shown that women are more likely to adopt behaviours that can lead to higher amounts of food waste: not prioritizing the consumption of food items based on expiration date and cooking more than the household can consume. Although the current study did not find any significant differences in the amount of food wasted by young males and females, previous studies have signalled that young women tend to waste more food than their male counterparts (Principato et al., 2015; Silvennoinen et al., 2014; Koivupuro et al., 2012). There is also partial support for the findings of other studies. For example, women with ages between 30 and 40 have better cooking skills and cook more often than their male counterparts, which could be a sign of the fact that the household responsibilities in Romanian families are divided based on gender and women are the ones responsible for cooking for the entire household, which is similar to findings from other countries (Koivupuro et al., 2012). Moreover, for the age categories over 40, it was found that women tend to buy food items that are not on the shopping list and to send more time shopping for food than men. However, contrary to what other studies have found in regard to the impact of the gender of the person responsible for grocery shopping (Koivupuro et al., 2012; Katajuuri et al., 2014), the current study found no significant difference between the food wasted by the men and women in these age categories.

The study also found certain major differences in regard to the attitudes towards food waste of men and women across age categories. For those under 20 years old, there are no differences, but as women age, they tend to develop a negative perspective on food waste to a larger extent than men. For example, for the age category between 20 and 30, women are more likely than men to experience feelings of guilt when throwing away food and to associate food waste with social inequality. The same is true for women and men in the age category between 40 and 50. This can be linked to previous studies which have signalled that women are more likely to feel guilty about wasting food because they are the ones responsible to feed the household and regard food waste as an ineffective use of resources (Graham-Rowe et al., 2012; Porpino et al., 2015). However, this study extends previous findings by showing that women are more likely than men to view food waste as a sign of social inequality and to worry about the situation of children from poor families who do not have enough to eat. Thus, the role of "good mother" appears to extend well beyond the members of the household in the case of women between 20 and 30 or between 40 and 50. However, it also has to be noticed that women between 30 and 40 no longer associate food waste to social inequality to a higher degree than men, instead associating it with financial irresponsibility. It 
Cantaragiu, R., (2019)

The impact of gender on food waste at the consumer level

appears that the women in this age category are more pragmatic than men when it comes to food waste.

All in all, it can be concluded that there are several marked differences in the behaviour of attitudes of males and females in regard to food consumption and food waste, which vary across gender categories. Further studies are necessary in order to validate the findings if we take into consideration the fact that the under 20 age category comprised only 7 males and 5 females and the over 60 age category comprised only 4 females and 10 males. Moreover, it would also be interesting to take into account other socio-demographic factors that could generate differences between genders such as the individual or household income and the composition of the household.

\section{Acknowledgements}

The author would like to thank professor Corina Pelău for the help provided during the data collection and the two reviewers for their helpful comments.

\section{Author Contributions}

The entire article was written by Cantaragiu Ramona.

\section{Funding}

This research received no specific grant from any funding agency in the public, commercial, or not - for - profit sectors.

\section{Disclosure Statement}

The author has no competing financial, professional, or personal interests from other parties.

\section{References}

1. Barr, S., (2007), Factors influencing environmental attitudes and behaviours: a UL case study of household waste management, Environment and Behavior, 39(4), 435-473.

2. Cappellini, B., Parsons, E., (2012), Practising thrift at dinner time: Meal time leftovers, sacrifice and family membership, The Sociological Review, 60(2), 121134.

3. Cholette, S., Ozluk, O., Ozsen, L., Ungson, G.R., (2003), Exploring purchasing preferences: Local and ecologically labelled foods, Journal of Consumer Marketing, 30(7), 563-572.

4. FAO, (2019), "Key facts on food loss and waste you should know!", Retrieved from www.fao.org/save-food/resources/keyfindings/en, Accessed July 172019.

52 S sciendo Studia Universitatis "Vasile Goldis" Arad. Economics Series Vol 29 Issue 4/2019

ISSN: 1584-2339; (online) ISSN: $2285-3065$

Web: publicatii.uvvg.ro/index.php/studiaeconomia. Pages $41-57$ 
Cantaragiu, R., (2019)

The impact of gender on food waste at the consumer level

5. Fusions, (2016), "Food waste definition", Retrieved from www.eufusions.org/index.php/about-food-waste/280-food-waste-definition, Accessed July 17, 2019.

6. Graham-Rowe, E., Jessop, D.C., Sparks, P., (2014), Identifying motivations and barriers to minimising household food waste. Resources, Conservation and Recycling, 84, 15-23.

7. Graham-Rowe, E., Jessop, D.C., Sparks, P., (2015), Predicting household food waste reduction using an extended theory of planned behaviour, Resources, Conservation and Recycling, 101, 194-202.

8. Jorissen, J., Priefer, C., Brautigam, K.R., (2015), Food waste generation at household level: Results of a survey among employees of two European research centers in Italy and Germany, Sustainability, 7(3), 1695-2715.

9. Katajajuuri, J.-M., Silvennoinen, K., Hartikainen, H., Heikkila, L., Reininkainen, A., (2014), Food waste in the Finish food chain, Journal of Cleaner Production, 73, 322-329.

10. Koivupuro, H.-K., Hartikainen, H., Silvennoinen, K., Katajajuuri, J.-M., Heikintalo, N., Reinikainen, A., Jalkanen, L., (2012), Influence of sociodemographical, behavioural and attitudinal factors on the amount of avoidable food waste generated in Finnish households. International Journal of Consumer Studies, 36(2), 183-191.

11. Lee, S., Paik, H.S., (2011), Korean household waste management and recycling behaviour, Building and Environment, 46, 1159-1166.

12. Lyndhurst, B., (2007), WRAP food behaviour consumer research - Findings from the qualitative phase, WRAP.

13. McCarthy, B., Liu, H.B., (2017), Food waste and the "green" consumer, Australasian Marketing Journal, 25(2), 126-132.

14. Porpino, G., (2016), Household food waste behavior: Avenues for future research, Journal of the Association for Consumer Research, 1(1), 41-51.

15. Principato, L., Secondi, L., Pratesi, C.A., (2015), Reducing food waste: an investigation on the behaviour of Italian youths, British Food Journal, 117(2), 731748.

16. Qi, D., Roe, B.E., (2016), Household food waste: Multivariate regression and principal components analysis of awareness and attitudes among U.S. consumers. PLoS ONE, 11(7), e0159250.

17. Secondi, L., Principato, L., Laureti, T., (2015), Household food waste behaviour in EU-27 countries: A multilevel analysis, Food Policy, 56, 25-40.

18. Setti, M., Falasconi, L., Vittuari, M., Andrea, S., Cusano, I., (2016), Italian consumers' income and food waste behaviour, British Food Journal, 118(7), 17311746. 
Cantaragiu, R., (2019)

The impact of gender on food waste at the consumer level

19. Silvennoinen, K., Katajajuuri, J.-M., Hartikainen, H., Heikkila, L., Reinkainen, A., (2014), Food waste volume and composition in Finnish households, British Food Journal, 116(6), 1058-1068.

20. Visschers, V.H.M., Wickli, N., Siegrist, M., (2016), Sorting out food waste behaviour: A survey on the motivators and barriers of self-reported amounts of food waste in households, Journal of Environmental Psychology, 45, 66-78.

Table 4 The impact of gender on food waste for age groups below 40

\begin{tabular}{|c|c|c|c|c|c|c|c|c|c|c|}
\hline \multirow[b]{2}{*}{ Item } & \multirow[b]{2}{*}{ Gender } & \multicolumn{3}{|c|}{ Under 20} & \multicolumn{3}{|c|}{ Between 20 and 30} & \multicolumn{3}{|c|}{ Between 30 and 40} \\
\hline & & $\mathbf{N}$ & Mean & $\begin{array}{l}\text { Std. } \\
\text { Dev. }\end{array}$ & $\mathbf{N}$ & Mean & $\begin{array}{l}\text { Std. } \\
\text { Dev. }\end{array}$ & $\mathbf{N}$ & Mean & $\begin{array}{l}\text { Std. } \\
\text { Dev. }\end{array}$ \\
\hline \multirow[t]{2}{*}{ I1 } & $\mathrm{M}$ & 7 & 4.000 & 1.7321 & 41 & 4.390 & 2.0479 & 25 & 4.600 & 2.0616 \\
\hline & $\mathrm{F}$ & 5 & 5.000 & .7071 & 59 & 4.746 & 2.0137 & 24 & 4.833 & 1.5228 \\
\hline \multirow[t]{2}{*}{ I2 } & $\mathrm{M}$ & 7 & 4.143 & 1.5736 & 41 & 4.683 & 2.0055 & 25 & 4.800 & 1.6073 \\
\hline & $\mathrm{F}$ & 5 & 4.800 & 1.9235 & 59 & 5.288 & 1.4745 & 24 & 5.000 & 1.9781 \\
\hline \multirow[t]{2}{*}{$\mathbf{I 3}$} & $\mathrm{M}$ & 7 & 2.857 & 1.6762 & 41 & 2.829 & 1.8695 & 25 & 3.080 & 1.8690 \\
\hline & $\mathrm{F}$ & 5 & 2.000 & 1.0000 & 59 & 2.831 & 1.8951 & 24 & 2.667 & 1.5228 \\
\hline \multirow[t]{2}{*}{ I4 } & $\mathrm{M}$ & 7 & 2.429 & 1.2724 & 41 & 2.780 & 1.5085 & 25 & 3.240 & 1.8092 \\
\hline & $\mathrm{F}$ & 5 & 2.400 & 1.6733 & 59 & 2.695 & 1.6109 & 24 & 2.625 & 1.9959 \\
\hline \multirow[t]{2}{*}{ I5 } & $\mathrm{M}$ & 7 & 4.286 & 1.6036 & 41 & 4.610 & 1.8958 & 25 & 4.400 & 1.8484 \\
\hline & $\mathrm{F}$ & 5 & 5.000 & 2.1213 & 59 & 4.508 & 1.7750 & 24 & 4.417 & 2.1853 \\
\hline \multirow[t]{2}{*}{ I6 } & M & 7 & 4.429 & 1.5119 & 41 & 3.902 & 1.9340 & 25 & 4.200 & 1.9579 \\
\hline & $\mathrm{F}$ & 5 & 4.800 & 2.1679 & 59 & 4.441 & 1.5566 & 24 & 4.292 & 1.9444 \\
\hline \multirow[t]{2}{*}{ I7 } & $\mathrm{M}$ & 7 & 4.714 & 1.7995 & 41 & 4.366 & 1.8132 & 25 & 5.200 & 1.6583 \\
\hline & $\mathrm{F}$ & 5 & 5.200 & .8367 & 59 & 4.966 & 1.6397 & 24 & 4.875 & 1.8489 \\
\hline \multirow[t]{2}{*}{ I8 } & $\mathrm{M}$ & 7 & 4.571 & .9759 & 41 & 3.293 & 1.7783 & 25 & 3.840 & 1.7720 \\
\hline & $\mathrm{F}$ & 5 & 4.000 & 1.2247 & 59 & 3.966 & 1.6185 & 24 & 3.750 & 1.5393 \\
\hline \multirow[t]{2}{*}{ I9 } & $\mathrm{M}$ & 7 & 5.857 & .8997 & 41 & 4.878 & 2.0024 & 25 & 5.000 & 1.9149 \\
\hline & $\mathrm{F}$ & 5 & 5.600 & .8944 & 59 & 5.593 & 1.6621 & 24 & 5.417 & 2.0624 \\
\hline \multirow[t]{2}{*}{ I10 } & $\mathrm{M}$ & 7 & 5.429 & .9759 & 41 & 4.195 & 1.8738 & 25 & 5.400 & 1.5275 \\
\hline & $\mathrm{F}$ & 5 & 5.200 & .8367 & 59 & 4.729 & 1.8922 & 24 & 5.083 & 2.0624 \\
\hline \multirow[t]{2}{*}{ I11 } & $M$ & 7 & 3.286 & 1.6036 & 41 & 2.756 & 1.9207 & 25 & 2.480 & 1.9175 \\
\hline & $\mathrm{F}$ & 5 & 3.400 & 1.1402 & 59 & 2.780 & 1.8389 & 24 & 2.750 & 1.7508 \\
\hline \multirow[t]{2}{*}{ I12 } & $\mathrm{M}$ & 7 & 4.143 & 2.6095 & 41 & 3.537 & 1.7478 & 25 & 3.920 & 1.3820 \\
\hline & $\mathrm{F}$ & 5 & 5.000 & .7071 & 59 & 4.153 & 1.9011 & 24 & 4.125 & 1.9850 \\
\hline \multirow[t]{2}{*}{ I13 } & $\mathrm{M}$ & 7 & 4.714 & 1.3801 & 41 & 4.634 & 1.7429 & 25 & 4.800 & 1.7559 \\
\hline & $\mathrm{F}$ & 5 & 5.000 & 1.2247 & 59 & 4.576 & 1.7927 & 24 & 5.125 & 1.8013 \\
\hline \multirow[t]{2}{*}{ I14 } & $\mathrm{M}$ & 7 & 5.429 & .5345 & 41 & 4.244 & 2.0589 & 25 & 4.600 & 1.9149 \\
\hline & $\mathrm{F}$ & 5 & 3.200 & 1.6432 & 59 & 4.475 & 1.8133 & 24 & 3.958 & 1.9886 \\
\hline \multirow{2}{*}{ I15 } & $\mathrm{M}$ & 7 & 2.857 & 2.4103 & 41 & 2.878 & 1.8734 & 25 & 2.160 & 1.4048 \\
\hline & $\mathrm{F}$ & 5 & 1.000 & .0000 & 59 & 2.576 & 1.9137 & 24 & 2.542 & 1.8645 \\
\hline \multirow[t]{2}{*}{ I16 } & $\mathrm{M}$ & 7 & 3.714 & 2.0587 & 41 & 3.805 & 1.9649 & 25 & 4.080 & 2.0191 \\
\hline & $\mathrm{F}$ & 5 & 3.600 & 1.3416 & 59 & 3.932 & 2.0667 & 24 & 3.792 & 2.2259 \\
\hline \multirow[t]{2}{*}{ I17 } & $\mathrm{M}$ & 7 & 5.571 & .9759 & 41 & 5.317 & 1.4738 & 25 & 4.680 & 1.8421 \\
\hline & $\mathrm{F}$ & 5 & 4.600 & 1.6733 & 59 & 5.085 & 1.6219 & 24 & 5.042 & 1.6806 \\
\hline \multirow[t]{2}{*}{ I18 } & $\mathrm{M}$ & 7 & 4.000 & 1.7321 & 41 & 3.683 & 1.6947 & 25 & 4.080 & 1.9983 \\
\hline & $\mathrm{F}$ & 5 & 4.600 & .8944 & 59 & 4.458 & 1.5461 & 24 & 4.750 & 1.9167 \\
\hline
\end{tabular}

Note: significant mean differences shown in grey highlight.

Source: Author's research results. 
Cantaragiu, R., (2019)

The impact of gender on food waste at the consumer level

\begin{tabular}{|c|c|c|c|c|c|c|c|c|c|c|}
\hline \multirow[b]{2}{*}{ Item } & \multirow[b]{2}{*}{ Gender } & \multicolumn{3}{|c|}{ Under 20} & \multicolumn{3}{|c|}{ Between 20 and 30} & \multicolumn{3}{|c|}{ Between 30 and 40} \\
\hline & & $\mathbf{N}$ & Mean & $\begin{array}{l}\text { Std. } \\
\text { Dev. }\end{array}$ & $\mathbf{N}$ & Mean & $\begin{array}{l}\text { Std. } \\
\text { Dev. }\end{array}$ & $\mathbf{N}$ & Mean & $\begin{array}{l}\text { Std. } \\
\text { Dev. }\end{array}$ \\
\hline \multirow[t]{2}{*}{ I19 } & $\mathrm{M}$ & 7 & 4.429 & 1.7182 & 41 & 4.220 & 1.8909 & 25 & 3.720 & 1.5948 \\
\hline & $\mathrm{F}$ & 5 & 4.400 & 1.1402 & 59 & 4.339 & 1.6672 & 24 & 5.583 & 1.1765 \\
\hline \multirow[t]{2}{*}{ I20 } & $M$ & 7 & 4.286 & 1.6036 & 41 & 3.293 & 1.7783 & 25 & 2.800 & 1.5275 \\
\hline & $\mathrm{F}$ & 5 & 2.600 & .8944 & 59 & 3.475 & 1.6646 & 24 & 3.958 & 2.0104 \\
\hline \multirow[t]{2}{*}{$\mathbf{I 2 1}$} & M & 7 & 4.714 & 1.3801 & 41 & 4.415 & 1.8838 & 25 & 4.320 & 1.5199 \\
\hline & $\mathrm{F}$ & 5 & 4.200 & 1.0954 & 59 & 4.492 & 1.6228 & 24 & 4.458 & 1.8411 \\
\hline \multirow[t]{2}{*}{$\mathbf{I 2 2}$} & $\mathrm{M}$ & 7 & 4.000 & 1.9149 & 41 & 3.829 & 1.7306 & 25 & 3.480 & 1.8511 \\
\hline & $\mathrm{F}$ & 5 & 2.800 & 1.3038 & 59 & 3.814 & 1.9868 & 24 & 2.708 & 1.8528 \\
\hline \multirow[t]{2}{*}{ I23 } & M & 7 & 3.714 & 2.5635 & 40 & 2.550 & 2.1597 & 25 & 2.720 & 2.2271 \\
\hline & $\mathrm{F}$ & 5 & 3.000 & 2.5495 & 59 & 3.288 & 2.3419 & 24 & 3.417 & 2.3941 \\
\hline \multirow[t]{2}{*}{ I24 } & M & 7 & 3.286 & 2.1381 & 41 & 1.732 & 1.5170 & 25 & 1.960 & 1.4855 \\
\hline & $F$ & 5 & 2.600 & 1.8166 & 59 & 2.390 & 2.0173 & 24 & 2.042 & 1.9444 \\
\hline \multirow[t]{2}{*}{ I25 } & $M$ & 7 & 3.000 & 1.8257 & 41 & 2.902 & 1.8001 & 25 & 2.960 & 1.8367 \\
\hline & $\mathrm{F}$ & 5 & 1.800 & 1.3038 & 59 & 3.254 & 1.8991 & 24 & 3.333 & 2.2198 \\
\hline \multirow[t]{2}{*}{ I26 } & $M$ & 7 & 5.143 & 2.1931 & 41 & 4.805 & 2.0398 & 25 & 4.480 & 1.8956 \\
\hline & $\mathrm{F}$ & 5 & 4.200 & .8367 & 59 & 4.847 & 1.7696 & 24 & 4.792 & 1.8411 \\
\hline \multirow[t]{2}{*}{ I27 } & $\mathrm{M}$ & 7 & 5.857 & 1.3452 & 41 & 5.976 & 1.5888 & 25 & 5.400 & 1.8708 \\
\hline & $\mathrm{F}$ & 5 & 6.400 & .5477 & 59 & 5.305 & 1.9936 & 24 & 5.958 & 1.4885 \\
\hline \multirow[t]{2}{*}{ I28 } & $\mathrm{M}$ & 7 & 2.000 & 1.1547 & 41 & 2.146 & 1.6056 & 25 & 2.360 & 1.7049 \\
\hline & $\mathrm{F}$ & 5 & 1.200 & .4472 & 59 & 2.339 & 1.6569 & 24 & 2.792 & 1.9777 \\
\hline \multirow[t]{2}{*}{ I29 } & $M$ & 7 & 2.857 & 1.0690 & 41 & 2.805 & 1.9264 & 25 & 2.960 & 1.6452 \\
\hline & $\mathrm{F}$ & 5 & 2.800 & 1.0954 & 59 & 3.390 & 1.8478 & 24 & 3.250 & 2.1518 \\
\hline \multirow[t]{2}{*}{ I30 } & $\mathrm{M}$ & 7 & 5.286 & .9512 & 41 & 4.195 & 2.1239 & 25 & 5.120 & 1.5631 \\
\hline & $\mathrm{F}$ & 5 & 4.000 & 1.5811 & 59 & 5.407 & 1.5213 & 24 & 5.583 & 1.6918 \\
\hline \multirow[t]{2}{*}{ I31 } & $\mathrm{M}$ & 7 & 5.429 & .9759 & 41 & 3.927 & 2.2067 & 25 & 3.720 & 1.6713 \\
\hline & $\mathrm{F}$ & 5 & 4.000 & 1.4142 & 59 & 4.475 & 1.7356 & 24 & 4.875 & 1.8252 \\
\hline \multirow[t]{2}{*}{ I32 } & $\mathrm{M}$ & 7 & 3.857 & 2.0354 & 41 & 3.439 & 2.0862 & 25 & 4.040 & 2.3360 \\
\hline & $\mathrm{F}$ & 5 & 4.200 & 1.7889 & 59 & 4.780 & 2.0516 & 24 & 4.500 & 2.3591 \\
\hline \multirow[t]{2}{*}{ I33 } & $M$ & 7 & 4.000 & 2.0817 & 41 & 3.366 & 2.1302 & 25 & 4.120 & 1.9000 \\
\hline & $\mathrm{F}$ & 5 & 4.600 & 1.6733 & 59 & 4.051 & 1.7755 & 24 & 4.083 & 2.0624 \\
\hline
\end{tabular}

Note: significant mean differences shown in grey highlight.

Source: Author's research results. 
Cantaragiu, R., (2019)

The impact of gender on food waste at the consumer level

Table 6 The impact of gender on food waste for age groups over 40

\begin{tabular}{|c|c|c|c|c|c|c|c|c|c|c|}
\hline \multirow[b]{2}{*}{ Item } & \multirow[b]{2}{*}{ Gender } & \multicolumn{3}{|c|}{ Between 40 and 50} & \multicolumn{3}{|c|}{ Between 50 and 60} & \multicolumn{3}{|c|}{ Over 60} \\
\hline & & $\mathbf{N}$ & Mean & $\begin{array}{l}\text { Std. } \\
\text { Dev. }\end{array}$ & $\mathbf{N}$ & Mean & $\begin{array}{l}\text { Std. } \\
\text { Dev. }\end{array}$ & $\mathbf{N}$ & Mean & $\begin{array}{l}\text { Std. } \\
\text { Dev. }\end{array}$ \\
\hline \multirow[t]{2}{*}{ I1 } & $\mathrm{M}$ & 17 & 5.176 & 1.6672 & 20 & 5.050 & 1.8489 & 10 & 4.800 & 2.0440 \\
\hline & $\mathrm{F}$ & 22 & 5.500 & 1.9457 & 18 & 4.944 & 2.3382 & 4 & 5.250 & 2.0616 \\
\hline \multirow[t]{2}{*}{ I2 } & $\mathrm{M}$ & 17 & 4.000 & 1.5811 & 20 & 4.800 & 2.0417 & 10 & 4.900 & 1.5239 \\
\hline & $\mathrm{F}$ & 22 & 5.273 & 1.5791 & 18 & 4.611 & 2.1458 & 4 & 5.500 & 1.2910 \\
\hline \multirow[t]{2}{*}{ I3 } & $\mathrm{M}$ & 17 & 3.294 & 2.0544 & 20 & 4.000 & 1.8353 & 10 & 4.000 & 2.2111 \\
\hline & $\mathrm{F}$ & 22 & 4.318 & 1.9853 & 18 & 4.444 & 2.4787 & 4 & 4.750 & 2.6300 \\
\hline \multirow[t]{2}{*}{ I4 } & $\mathrm{M}$ & 17 & 3.118 & 1.8669 & 20 & 3.150 & 1.9541 & 10 & 4.000 & 1.7638 \\
\hline & $\mathrm{F}$ & 22 & 2.455 & 1.8955 & 18 & 2.778 & 2.2111 & 4 & 4.000 & 2.4495 \\
\hline \multirow[t]{2}{*}{ I5 } & $\mathrm{M}$ & 17 & 3.824 & 1.9760 & 20 & 4.800 & 1.7652 & 10 & 5.000 & 1.8257 \\
\hline & $\mathrm{F}$ & 22 & 4.227 & 1.9984 & 18 & 4.611 & 1.7868 & 4 & 6.250 & .9574 \\
\hline \multirow[t]{2}{*}{ I6 } & $\mathrm{M}$ & 17 & 4.235 & 1.9852 & 20 & 3.950 & 1.7313 & 10 & 3.500 & 1.6499 \\
\hline & $\mathrm{F}$ & 22 & 3.818 & 2.0386 & 18 & 3.333 & 1.9097 & 4 & 4.250 & .9574 \\
\hline \multirow[t]{2}{*}{ I7 } & $\mathrm{M}$ & 17 & 4.294 & 1.7946 & 20 & 4.500 & 1.6702 & 10 & 4.100 & 1.5951 \\
\hline & $\mathrm{F}$ & 22 & 4.682 & 1.9612 & 18 & 4.556 & 1.8542 & 4 & 5.000 & 1.8257 \\
\hline \multirow[t]{2}{*}{ I8 } & $\mathrm{M}$ & 17 & 3.824 & 1.8451 & 20 & 3.050 & 1.7313 & 10 & 3.300 & 1.4181 \\
\hline & $\mathrm{F}$ & 22 & 3.636 & 1.8138 & 18 & 3.389 & 1.6139 & 4 & 4.750 & 1.8930 \\
\hline \multirow[t]{2}{*}{ I9 } & $\mathrm{M}$ & 17 & 4.824 & 2.0073 & 20 & 3.850 & 2.2070 & 10 & 3.800 & 2.2010 \\
\hline & $\mathrm{F}$ & 22 & 4.909 & 2.0910 & 18 & 3.611 & 2.0903 & 4 & 5.500 & 1.7321 \\
\hline \multirow[t]{2}{*}{ I10 } & $\mathrm{M}$ & 17 & 3.882 & 1.9001 & 20 & 4.600 & 1.9574 & 10 & 5.500 & .9718 \\
\hline & $\mathrm{F}$ & 22 & 5.136 & 1.9832 & 18 & 5.556 & 1.1490 & 4 & 5.250 & .5000 \\
\hline \multirow[t]{2}{*}{ I11 } & $\mathrm{M}$ & 17 & 3.529 & 2.1248 & 20 & 3.000 & 2.0000 & 10 & 3.200 & 1.4757 \\
\hline & $\mathrm{F}$ & 22 & 2.591 & 1.3683 & 18 & 3.389 & 2.0903 & 4 & 4.750 & 1.5000 \\
\hline \multirow[t]{2}{*}{ I12 } & $\mathrm{M}$ & 17 & 3.588 & 1.8048 & 20 & 2.950 & 1.5720 & 10 & 3.600 & 1.5055 \\
\hline & $\mathrm{F}$ & 22 & 4.091 & 2.0215 & 18 & 4.222 & 2.2637 & 4 & 4.500 & 1.9149 \\
\hline \multirow[t]{2}{*}{ I13 } & $\mathrm{M}$ & 17 & 4.294 & 2.0544 & 20 & 3.550 & 1.8202 & 10 & 2.900 & 1.5951 \\
\hline & $\mathrm{F}$ & 22 & 4.182 & 1.9673 & 18 & 4.333 & 2.0580 & 4 & 4.250 & 1.7078 \\
\hline \multirow[t]{2}{*}{ I14 } & $\mathrm{M}$ & 17 & 4.647 & 1.8689 & 20 & 4.500 & 1.9601 & 10 & 4.700 & 2.1628 \\
\hline & $\mathrm{F}$ & 22 & 4.682 & 2.0092 & 18 & 5.667 & 2.0000 & 4 & 4.750 & 1.5000 \\
\hline \multirow[t]{2}{*}{ I15 } & $\mathrm{M}$ & 17 & 2.647 & 1.5788 & 20 & 2.850 & 1.9808 & 10 & 3.100 & 1.7920 \\
\hline & $\mathrm{F}$ & 22 & 2.455 & 2.1762 & 18 & 3.444 & 2.6172 & 4 & 4.500 & 1.9149 \\
\hline \multirow[t]{2}{*}{ I16 } & $\mathrm{M}$ & 17 & 4.059 & 1.8190 & 20 & 4.150 & 2.2542 & 10 & 3.600 & 1.9551 \\
\hline & $\mathrm{F}$ & 22 & 3.500 & 2.3248 & 18 & 3.722 & 2.2441 & 4 & 5.750 & 1.8930 \\
\hline \multirow[t]{2}{*}{ I17 } & $\mathrm{M}$ & 17 & 4.824 & 1.8451 & 20 & 5.000 & 1.7168 & 10 & 4.000 & 1.8257 \\
\hline & $\mathrm{F}$ & 22 & 5.182 & 1.8679 & 18 & 5.222 & 1.8329 & 4 & 5.000 & 2.1602 \\
\hline \multirow[t]{2}{*}{ I18 } & $\mathrm{M}$ & 17 & 3.941 & 1.7843 & 20 & 3.600 & 2.2100 & 10 & 4.100 & 1.9120 \\
\hline & $\mathrm{F}$ & 22 & 4.955 & 1.8892 & 18 & 4.389 & 1.6499 & 4 & 5.500 & 1.0000 \\
\hline
\end{tabular}

Note: significant mean differences shown in grey highlight.

Source: Author's research results. 
Cantaragiu, R., (2019)

The impact of gender on food waste at the consumer level

\begin{tabular}{|c|c|c|c|c|c|c|c|c|c|c|}
\hline \multirow[b]{2}{*}{ Item } & \multirow[b]{2}{*}{ Gender } & \multicolumn{3}{|c|}{ Between 40 and 50} & \multicolumn{3}{|c|}{ Between 50 and 60} & \multicolumn{3}{|c|}{ Over 60} \\
\hline & & $\mathbf{N}$ & Mean & $\begin{array}{l}\text { Std. } \\
\text { Dev. }\end{array}$ & $\mathbf{N}$ & Mean & $\begin{array}{l}\text { Std. } \\
\text { Dev. }\end{array}$ & $\mathbf{N}$ & Mean & $\begin{array}{l}\text { Std. } \\
\text { Dev. }\end{array}$ \\
\hline \multirow[t]{2}{*}{ I19 } & $\mathrm{M}$ & 17 & 4.235 & 1.9852 & 20 & 3.900 & 1.9974 & 10 & 3.600 & 1.4298 \\
\hline & $\mathrm{F}$ & 22 & 5.091 & 1.7157 & 18 & 5.056 & 1.7978 & 4 & 5.000 & 2.1602 \\
\hline \multirow[t]{2}{*}{ I20 } & $\mathrm{M}$ & 17 & 4.235 & 2.2508 & 20 & 4.850 & 2.0844 & 10 & 5.400 & 1.8974 \\
\hline & $\mathrm{F}$ & 22 & 5.318 & 1.7832 & 18 & 5.500 & 1.7573 & 4 & 6.250 & .9574 \\
\hline \multirow[t]{2}{*}{ I21 } & $\mathrm{M}$ & 17 & 4.118 & 2.0274 & 20 & 5.150 & 1.7252 & 10 & 5.600 & .6992 \\
\hline & $\mathrm{F}$ & 22 & 4.364 & 1.7606 & 18 & 5.333 & 1.7823 & 4 & 6.250 & .5000 \\
\hline \multirow[t]{2}{*}{$\mathbf{I 2 2}$} & $\mathrm{M}$ & 17 & 3.000 & 2.1213 & 20 & 2.350 & 1.4244 & 10 & 1.300 & .4830 \\
\hline & $\mathrm{F}$ & 22 & 2.773 & 1.9256 & 18 & 2.333 & 1.6450 & 4 & 1.500 & .5774 \\
\hline \multirow[t]{2}{*}{ I23 } & $\mathrm{M}$ & 17 & 3.412 & 2.3200 & 20 & 3.850 & 2.4767 & 9 & 5.333 & 1.8708 \\
\hline & $\mathrm{F}$ & 22 & 4.227 & 2.5807 & 18 & 4.889 & 2.3736 & 4 & 5.500 & 2.3805 \\
\hline \multirow[t]{2}{*}{ I24 } & $\mathrm{M}$ & 17 & 2.235 & 1.9852 & 20 & 2.350 & 1.8144 & 10 & 3.200 & 1.9322 \\
\hline & $\mathrm{F}$ & 22 & 1.727 & 1.5176 & 18 & 2.389 & 2.0619 & 4 & 4.250 & 2.0616 \\
\hline \multirow[t]{2}{*}{ I25 } & $\mathrm{M}$ & 17 & 2.471 & 1.8748 & 20 & 2.450 & 1.7006 & 10 & 2.300 & 1.2517 \\
\hline & $\mathrm{F}$ & 22 & 3.318 & 2.5145 & 18 & 2.389 & 1.8515 & 4 & 1.500 & 1.0000 \\
\hline \multirow[t]{2}{*}{ I26 } & $\mathrm{M}$ & 17 & 4.176 & 2.2146 & 20 & 4.450 & 2.1392 & 10 & 4.400 & 1.9551 \\
\hline & $\mathrm{F}$ & 22 & 4.045 & 2.2986 & 18 & 4.333 & 1.8150 & 4 & 5.250 & 2.3629 \\
\hline \multirow[t]{2}{*}{ I27 } & $\mathrm{M}$ & 17 & 5.941 & 1.8531 & 20 & 5.950 & 2.1879 & 10 & 4.500 & 2.0683 \\
\hline & $\mathrm{F}$ & 22 & 6.500 & 1.3363 & 18 & 5.278 & 2.3466 & 4 & 5.000 & 2.1602 \\
\hline \multirow[t]{2}{*}{ I28 } & $\mathrm{M}$ & 17 & 3.118 & 2.1472 & 20 & 2.800 & 1.8238 & 10 & 3.000 & 2.0000 \\
\hline & $\mathrm{F}$ & 22 & 3.273 & 1.7233 & 18 & 3.278 & 1.9943 & 4 & 5.000 & 2.1602 \\
\hline \multirow[t]{2}{*}{ I29 } & $\mathrm{M}$ & 17 & 2.765 & 1.6405 & 20 & 2.150 & 1.2258 & 10 & 2.000 & .8165 \\
\hline & $\mathrm{F}$ & 22 & 3.045 & 1.8892 & 18 & 2.722 & 1.9344 & 4 & 2.000 & 1.4142 \\
\hline \multirow[t]{2}{*}{ I30 } & $\mathrm{M}$ & 17 & 4.941 & 2.0454 & 20 & 5.850 & 1.5313 & 10 & 5.700 & 1.2517 \\
\hline & $\mathrm{F}$ & 22 & 4.955 & 1.9634 & 18 & 4.944 & 2.1821 & 4 & 6.500 & 1.0000 \\
\hline \multirow[t]{2}{*}{ I31 } & $\mathrm{M}$ & 17 & 4.353 & 1.9982 & 20 & 4.600 & 2.0365 & 10 & 4.300 & 1.9465 \\
\hline & $\mathrm{F}$ & 22 & 4.682 & 1.8358 & 18 & 4.667 & 2.1963 & 4 & 4.750 & 2.2174 \\
\hline \multirow[t]{2}{*}{ I32 } & $\mathrm{M}$ & 17 & 3.059 & 2.1057 & 20 & 4.900 & 2.0235 & 10 & 5.600 & 1.5055 \\
\hline & $\mathrm{F}$ & 22 & 4.864 & 1.7264 & 18 & 4.722 & 1.9646 & 4 & 6.750 & .5000 \\
\hline \multirow[t]{2}{*}{ I33 } & $\mathrm{M}$ & 17 & 3.059 & 2.0758 & 20 & 3.950 & 1.9595 & 10 & 5.200 & 1.3984 \\
\hline & $\mathrm{F}$ & 22 & 4.045 & 1.9875 & 18 & 4.167 & 2.0073 & 4 & 6.250 & .5000 \\
\hline
\end{tabular}

Note: significant mean differences shown in grey highlight.

Source: Author's research results. 